Thiede, R., Robert, X., Stübner, K., Dey, S., and Faruhn, J., 2017, Sustained out-of-sequence shortening along a tectonically active segment of the Main Boundary thrust: The Dhauladhar Range in the northwestern Himalaya: Lithosphere, doi:10.1130/L630.1.

\title{
Analytical details
}

\section{Zircon U-Th/He-Dating:}

We conducted standard mineral separation procedures at the University of Potsdam. All samples yielded high quantity of zircon phenocrystals. By handpicking, suitably sized (80-150 $\mu \mathrm{m})$ pristine zircon grains were screened for inclusions, cracks and their state of alteration using a binocular microscope magnification. Grain dimensions were measured for the calculation of the alpha-correction factor after Farley et al. (1996). Afterwards the single grains were packed in Nb-tubes for single grains (U-Th)/He analysis and measured at the University of Tübingen. We extracted helium using a Patterson Helium extraction line, which is equipped with a $960 \mathrm{~nm}$ diode laser. We dissolved the grain packages after Helium analysis for U, Th, and Sm concentrations measurements using an ICP-MS. Analytical procedures are described in Stübner et al., (2016). At least three aliquot replicates per sample have been analyzed. The analytical errors of the mass spectrometer measurements are generally very low and do not exceed $2 \%$. In contrast, the reproducibility of the sample age constitutes a much larger error. We therefore report the mean (U-Th)/He age and the standard deviation of the measured aliquots as the sample error. For single-grain ages, we apply a 3\% 1-sigma-error based on the reproducibility of standard measurements in the lab (Fig. 3; Table 1). 


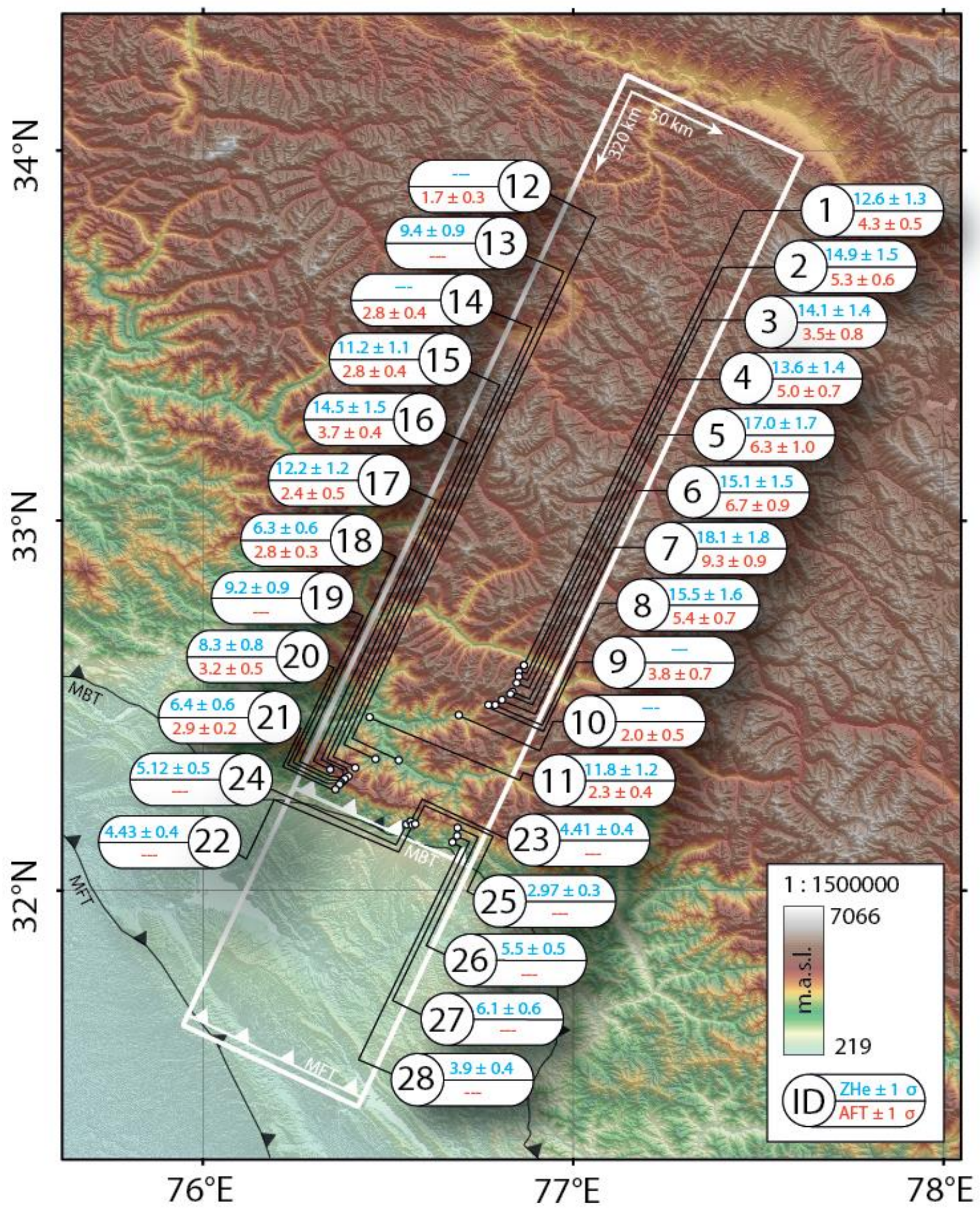

Figure S1: Outline of the PECUBE model (white box) and locations of thermochronometric data used for PECUBE numerical modeling. The Main Frontal Thrust (MFT) and the Main Boundary Thrust (MBT) are implemented as fault planes consisting of several segments that dip parallel to the main tectonic transport direction (see Figure S3). Sample numbers correspond to Table 1.

\section{PECUBE forward and inverse modeling}

We modelled the thermal-kinematic evolution of the Dhauladar Range in the NW Himalaya using the PECUBE model (Braun et al., 2012) by forward and inverse modeling. Material properties and model dimensions were identical for all models and are listed in Table S1. The model is a $320 \mathrm{~km} \mathrm{x} 50 \mathrm{~km}$ swath parallel to the main tectonic transport direction $\left(025^{\circ} \mathrm{NNE}\right.$; (Kundu et al., 2014)). It includes all 
sample localities included in thermokinematic inversion (Figure S1). The most linear segments of the Dhauladar Range and the MBT and MFT are located along the southern model boundary. All fault segments dip parallel to the swath, i.e., horizontal material transport in the models is parallel to the swath. The length of the swath is sufficient to include the complete particle trajectories of all evaluated data points (Huntington et al., 2007; Braun et al., 2012).

The topography is derived from a SRTM V2 digital elevation model resampled to a resolution of $\sim 3$ $\mathrm{km}$, which is considered appropriate for the relief of the Dhauladar Range (valley spacing $\sim 30 \mathrm{~km}$; c.f. Valla et al., 2011). Repeat experiments with different spatial resolutions (1 km, $3 \mathrm{~km}, 9 \mathrm{~km})$ support this choice.

Modeled faults comprise the MFT and MBT and their common basal fault, the MHT (Figure S1). We explored four different geometric relationships between MBT, MFT and MHT (Figure S2). The depth and geometry of the MHT is based on cross-section reconstruction and seismic data (e.g., Powers et al., 1998; Schulte-Pelkum et al., 2005; Rajendra Prasad et al., 2011). In model fault geometries 1 and 3-4 we assumed MHT dip 3-5 $5^{\circ}$ taken from the literature, we kept the junction of MHT and MBT fixed at $10 \mathrm{~km}$ depth. The dip of the MFT is kept fix at $15^{\circ}$ to fixed depth of $4 \mathrm{~km}$; the dip of the MBT is varied $20-60^{\circ}$.

\begin{tabular}{|c|c|c|c|c|}
\hline Parameter & Notation & $\begin{array}{l}\text { Model input } \\
\text { value }\end{array}$ & Unit & Comment \\
\hline \multicolumn{5}{|l|}{ Material properties } \\
\hline Crustal density & $\partial c$ & 2800 & g. $\mathrm{cm}^{-3}$ & \multirow{7}{*}{ dimensionless } \\
\hline Mantle density & $\partial m$ & 3200 & g.cm $\mathrm{cm}^{-3}$ & \\
\hline Young's modulus & $\mathrm{E}$ & $1 \times 10^{11}$ & $\mathrm{~Pa}$ & \\
\hline Poisson's ratio & $\mu$ & 0.25 & & \\
\hline Elastic thickness & & 28.8 & $\mathrm{~km}$ & \\
\hline & & & $\mathrm{km}^{2}$ & \\
\hline Heat diffusivity & & $25-60$ & $\mathrm{Myr}^{-1}$ & \\
\hline \multicolumn{5}{|l|}{ Thermal properties } \\
\hline Basal temperature & $T$ & $600-1200$ & ${ }^{\circ} \mathrm{C}$ & fixed temperature at the base \\
\hline Surface temperature & $\mathrm{T}$ & 20 & ${ }^{\circ} \mathrm{C}$ & Surface $T$ is set to atmospheric lapse rate \\
\hline Atmospheric lapse rate & $\partial T / \partial z$ & 6 & $\begin{array}{c}{ }^{\circ} \mathrm{C} \mathrm{km}^{-} \\
1\end{array}$ & \\
\hline $\begin{array}{l}\text { Internal heat production } \\
\text { rate }\end{array}$ & $\partial T / \partial t$ & $0-45$ & $\begin{array}{c}{ }^{\circ} \mathrm{C} \\
\mathrm{Myr}^{-1}\end{array}$ & \\
\hline
\end{tabular}




\begin{tabular}{|c|c|c|c|c|}
\hline \multicolumn{5}{|l|}{ Model dimensions } \\
\hline Width & $\mathrm{x}$ & 50 & $\mathrm{~km}$ & \\
\hline Length & $\mathrm{Y}$ & 320 & $\mathrm{~km}$ & \\
\hline Thickness & Z & 25 & $\mathrm{~km}$ & \\
\hline \multicolumn{5}{|l|}{ Fault geometries } \\
\hline MBT dip angle & & $20-60$ & $\circ$ & \\
\hline MFT dip angle & & 15 & $\circ$ & \\
\hline MHT dip angle & & 03-05 & $\circ$ & \\
\hline Shortening direction & & N 025 & $\circ$ & \\
\hline \multicolumn{5}{|l|}{ Fault kinematics } \\
\hline Overthrusting rate $\mathrm{MBT}$ & $\begin{array}{c}\mathrm{v} \\
\mathrm{o}(\mathrm{MBT})\end{array}$ & $1-5$ & $\begin{array}{l}\mathrm{mm} \\
\mathrm{yr}^{-1}\end{array}$ & time-dependent \\
\hline $\begin{array}{l}\text { Overthrusting rate } \\
\text { MFT/MHT }\end{array}$ & $\begin{array}{c}\mathrm{v} \\
\mathrm{o}(\mathrm{MFT}, \mathrm{M} \\
\mathrm{HT})\end{array}$ & $06-09$ & $\begin{array}{l}\mathrm{mm} \\
\mathrm{yr}^{-1}\end{array}$ & time-dependent \\
\hline $\begin{array}{l}\text { Underthrusting rate } \\
\mathrm{MFT} / \mathrm{MHT}\end{array}$ & $\begin{array}{c}\mathrm{v} \\
\mathrm{u}(\mathrm{MFT}, \mathrm{M} \\
\mathrm{HT})\end{array}$ & 5 & $\begin{array}{l}\mathrm{mm} \\
\mathrm{yr}^{-1}\end{array}$ & time invariant \\
\hline Total convergence rate & $\mathrm{v}_{\text {conv }}$ & 14 & $\begin{array}{l}\mathrm{mm} \\
\mathrm{yr}^{-1}\end{array}$ & constant, $\mathrm{v}_{\text {conv }}=\mathrm{v}_{\mathrm{o}(\mathrm{MBT})}+\mathrm{v}_{\mathrm{o}(\mathrm{MFT}, \mathrm{MHT})}+\mathrm{v}_{\mathrm{u}(\mathrm{MFT}, \mathrm{MHT})}$ \\
\hline
\end{tabular}

\section{Spatial boundaries and model resolution}

We chose this spatial boundary to fulfill requirements for geodynamic modeling, which are in our case: (1) The model width reflects the most linear part of the central Dhauladhar range, its bounding faults, and most analyzed cooling ages are located in. (2) The code PECUBE just allows runs orthogonal to the fault's surface trace, which strikes $115^{\circ}$ ESE in our case. (3) The length supplies our model with enough material, when taking the lateral particle trajectories into account (Huntington et al., 2007; Braun et al., 2012). (4) Finally the rectangularity guaranties as low as possible edge-interferences while having an efficient computing capacity bounding all taken samples.

We extracted the surface topography from a SRTM V2 digital elevation model with a resolution of $90 \mathrm{~m}$ per pixel. We downgraded this resolution to $\sim 3 \mathrm{~km}$ to (1) allow a fluent performance of the code run and to (2) obtain minimal reasonable results for calculation of ages and exhumation rates. (Valla et al., 2011; Coutand et al., 2014) show that the threshold for acceptable results ranges between $750 \mathrm{~m}$ and $1000 \mathrm{~m}$ per cell. Above this resolution (smaller cell size) no further improvement of the inversion predictions is attainable, while in 
contrast lower resolutions (increased cell size) leads to a rising error. Regardless to this restriction, Valla et al. (2011) also points out that optimal information on relief and denudation can be obtained from a spatial resolution, which covers around $10 \%$ of the topographic wavelength. The valley spacing around the Dhauladhar range is around $30 \mathrm{~km}$ with amplitude of $\sim 3 \mathrm{~km}$. Therefore the resolution of $3 \mathrm{~km}$ that we used seems to be meaningful. Nevertheless, we conducted several inversions with different resolutions $(1 \mathrm{~km}, 3$ $\mathrm{km}, 9 \mathrm{~km}$ ) that show that best results are obtained with a $3 \mathrm{~km}$ resolution.

\section{$\underline{\text { Kinematic model }}$}

Besides the three main thrust structures (MFT, MBT, MHT) we build no additional faults such as the MCT or the contemporaneous frontal fault and Sub-Himalayan thrust belt.

We obtained a very good correlation between observed and predicted ages with the geometry I (Fig. 4). The exhumation rate (Fig 4, grey line) shows a vigorous exhumation at the front, moderate rates further north.

We observed a different situation by extending a deep-seated MBT ramp beneath the frontal range (S2, 4, Geometry II). While the apparent correlation between the observed and predicted ages and a related distinct age-elevation relationship had been shifted to the Pir Panjal area, the frontal range yields far too young ages.

Geometry III with a typical central Himalayan setting of the décollement (Fig. 4) prove the absence of a mid-crustal ramp within the Dhauladhar segment. There, a step along the MHT trace forces the particle paths to bend upwards, producing a higher exhumation rate beneath the Pir Panjal. This "flat-ramp" - structure is also inferred for the neighboring regions, where tectonic windows are interpreted as a result from higher exhumation rates above hinterland mid-crustal ramps (Robert et al., 2009, Hermann et al., 2010).

Geometry IV (Fig. 4) evaluates, if a duplex structure beneath the Pir Panjal range could yield reliable modeled ages. The obtained slow exhumation and the absence of any localized uplifted structure also negating the presence of such a stacked thrust sheet structure. Contrary to all prior models, a narrow high-uplift zone evolves at the orogenic front, but the high exhumation rates stay constant throughout the whole model length and shows only minor variations along its trace.

The slip rate on the MBT and the related uplift rate, which is closely related to the angle of this fault that has the largest influence in the predicted surface age pattern (Fig. S3). The range in ages is largest between $1 \mathrm{~mm} \mathrm{yr}^{-1}$ and $5 \mathrm{~mm} \mathrm{yr}^{-1}$ slip rate. The zero rate had been included to investigate a purely temperature driven uplift across the MBT, while the décollement acts as a source of horizontal advection and motion only. Depending on both, slip rate and dip angle, the vertical uplift rate varies between $0.9 \mathrm{~mm} \mathrm{yr}^{-1}$ and $2 \mathrm{~mm} \mathrm{yr}^{-1}$. 


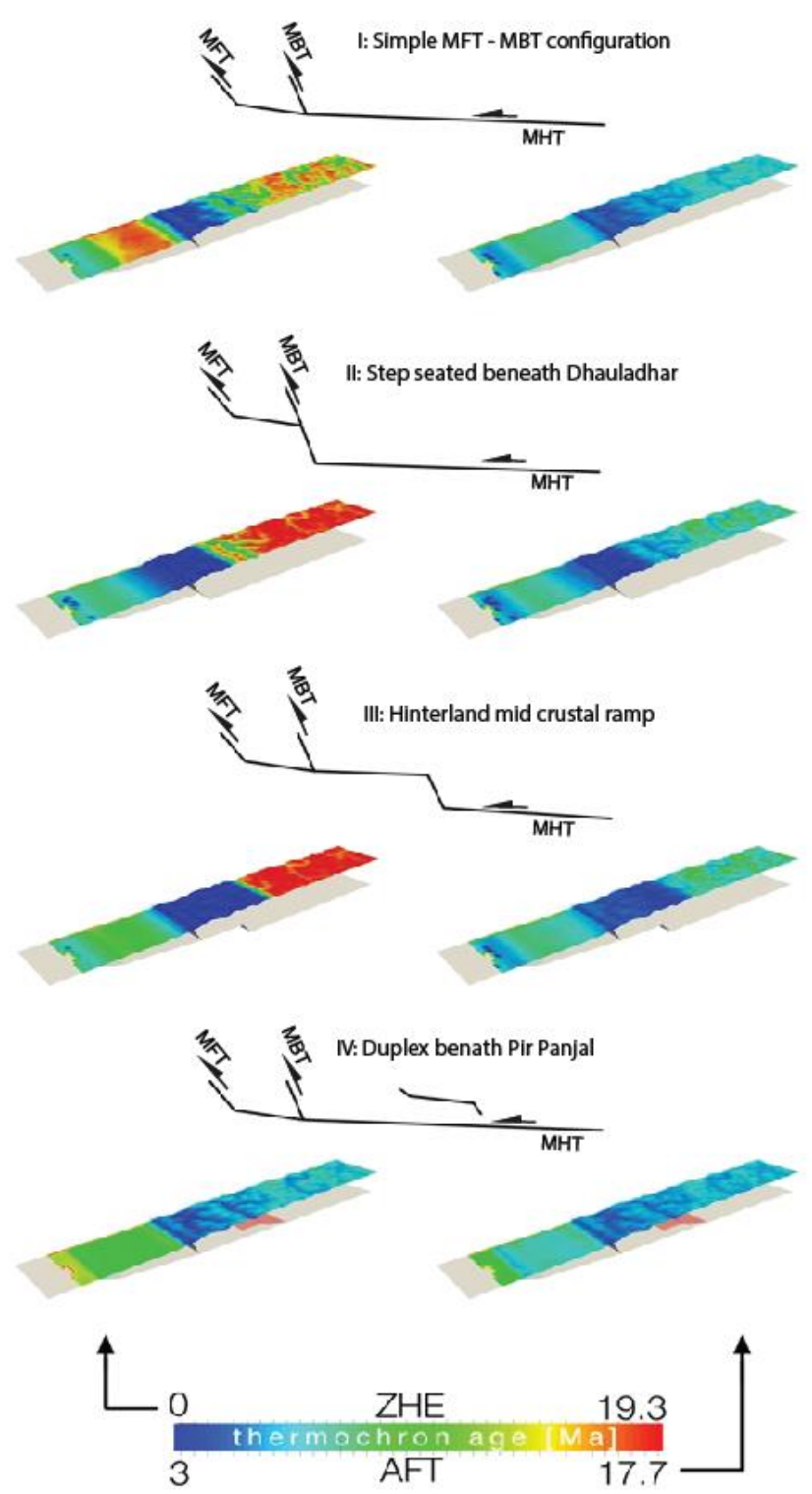

Fig. S2 Different model geometries and their resulting surface age pattern. All models comprise the same thermal properties as well as velocity parameters (DR-table 1). The simple line drawings show the relation between all involved fault architectures. 

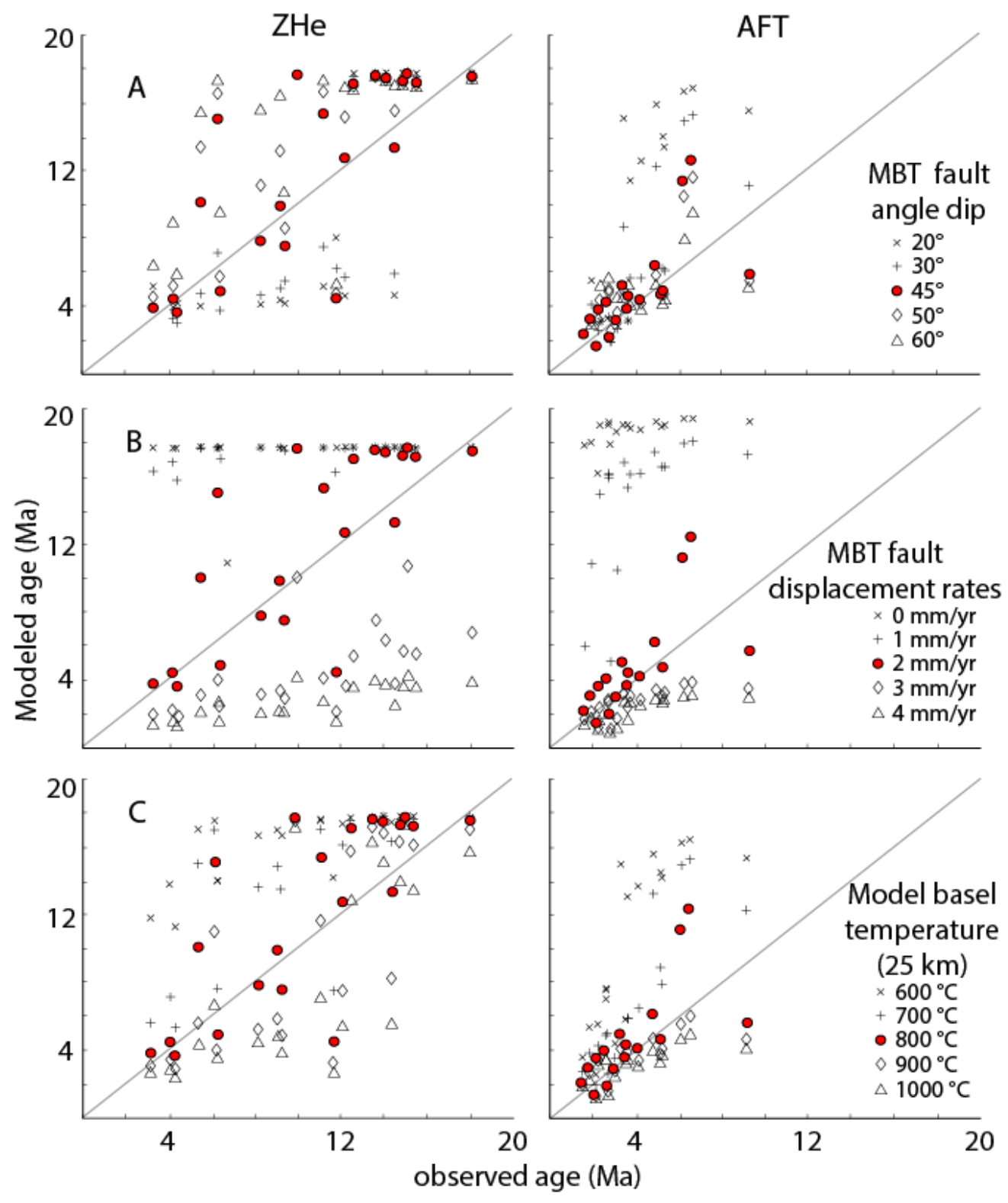

Fig. S3: To explore the parameter space we compare observed and predicted AFT and ZHe ages with models where only one parameter is varying, while the other inputs remain constant. We explored the affect in A) variation of the dip angle of the MBT ramp; B) the MBT overthrusting slip rate, and C) the basal temperature at $25 \mathrm{~km}$ depth. Red dots denote the lowest misfit between observed and predicted ages.

Low MBT slip rates little affect ZHe ages at the front and do not influence the interior part (Fig S3, S4). From medium velocities, its influence is more and more pronounced throughout the whole model length. This is inversely related to the AFT ages, were low slip rates show a vast influx, but high rates produce a smaller cluster. The most favorable slip rate is around 2 $3 \mathrm{~mm} . \mathrm{yr}^{-1}$. 


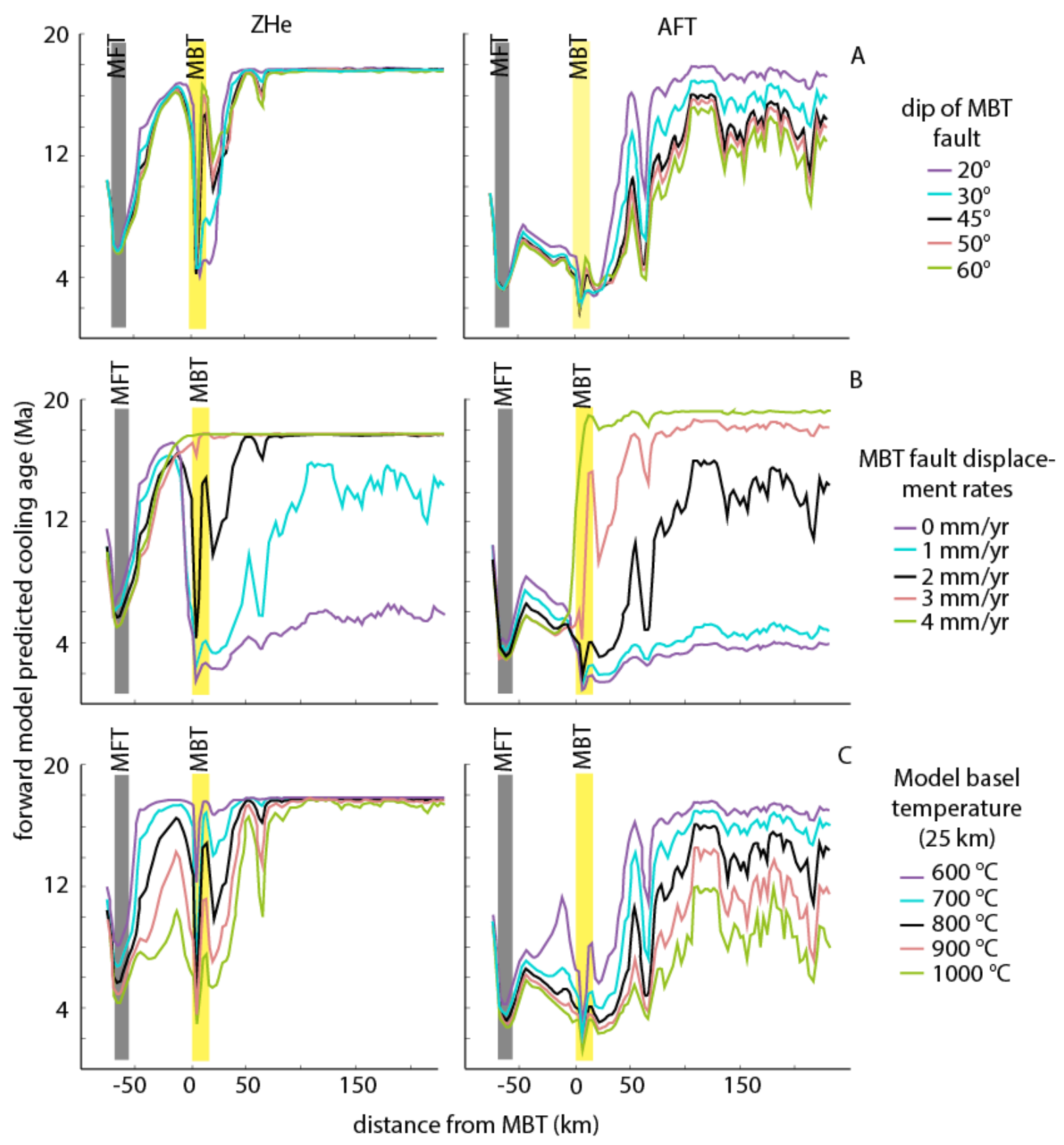

Figure S4: By comparison of forward model predicted AFT and ZHe ages along the studied transect perpendicular to the MBT, we explored the parameter space. Always only one parameter is varied, while the other inputs remain constant. A) Eporing the range different dip angles of the MBT ramp; B) MBT overthrusting slip rate and; C) effect of the model basal temperature at $25 \mathrm{~km}$ depth. Grey areas represent location of main fault zones, MFT and MBT.

The fault-ramp angle of the MBT mainly effects ZHe ages at the front while the same thermochronometer remains relatively unaffected across the Pir Panjal (Fig. S4). Despite three disturbed AFT ages, this fault-ramp angle has only minor effects on the predicted AFT ages along both, the front and the interior. The lowest misfit between observed and predicted ages in relation to the frontal fault dip lays around $40-45^{\circ}$. 

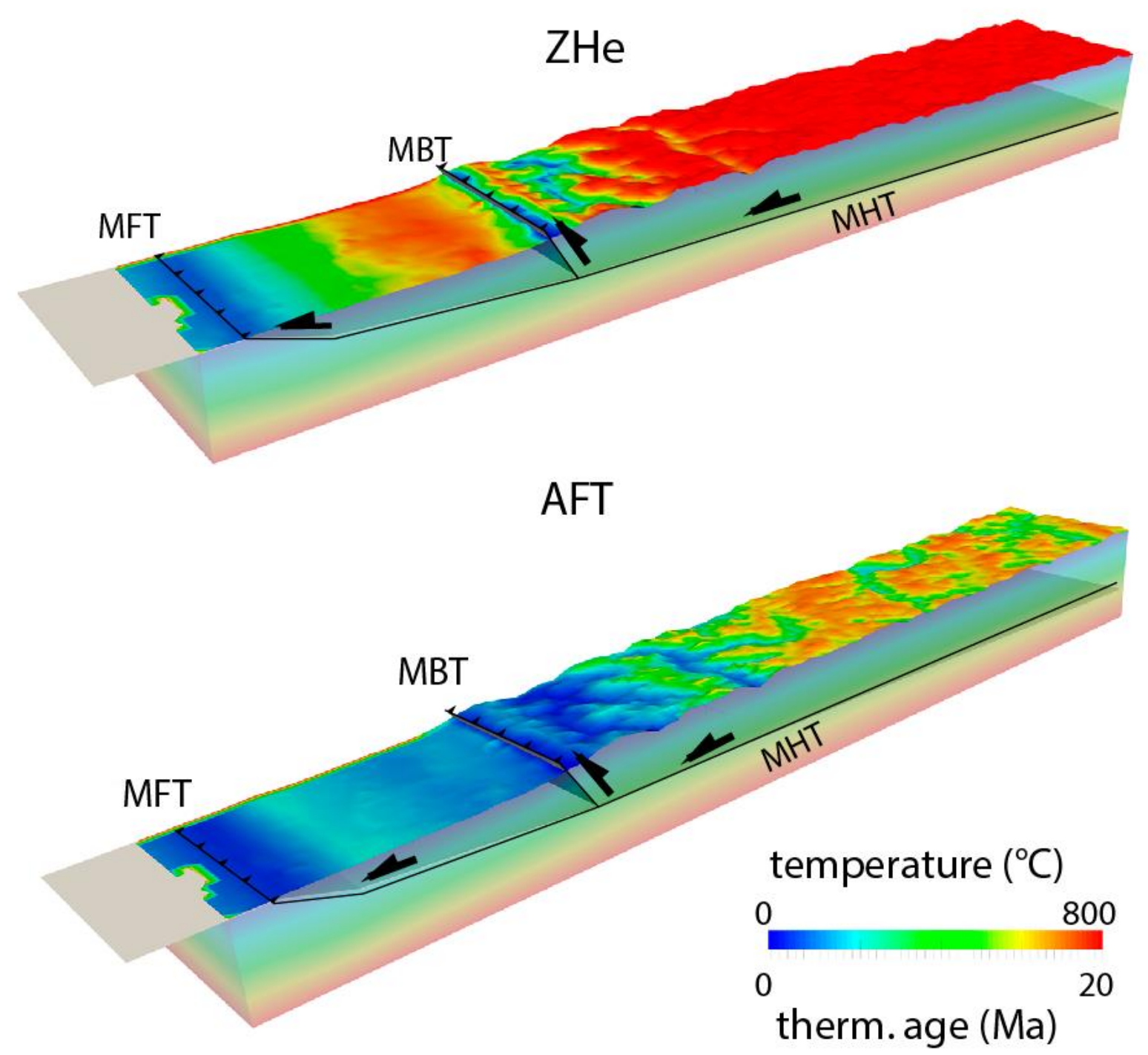

Figure S5: 3D representation of the modeled surface age pattern obtained from the best forward model. The surface color-coding indicates the modeled surface ZHe and AFT ages while the z-color pattern gives the temperature field.

\section{Thermal Parameters:}

Results are presented in Fig. S6 and show that the t. Thermal parameters are not well constrained, but in geologic meaning full range. But the lowest misfit values give a thermal diffusivity between 30 and $50 \mathrm{~km}^{2} / \mathrm{Myr}$. In contrast, the internal heat production scatters mostly between 3 and $35^{\circ} \mathrm{C} / \mathrm{Myr}$. The basal temperature $\left(25 \mathrm{~km}\right.$ depth) varies 650 and $750^{\circ} \mathrm{C}$, yielding model wide geothermal gradient from $\sim 30$ to $40^{\circ} \mathrm{C} / \mathrm{km}$. Despite high exhumation rates in the MBT hanging wall, the geotherms are only moderately deflected, which might be explained by its close position to the orogenic front, where cold Indian basement underthrusts the wedge tip and influences the thermal field. 

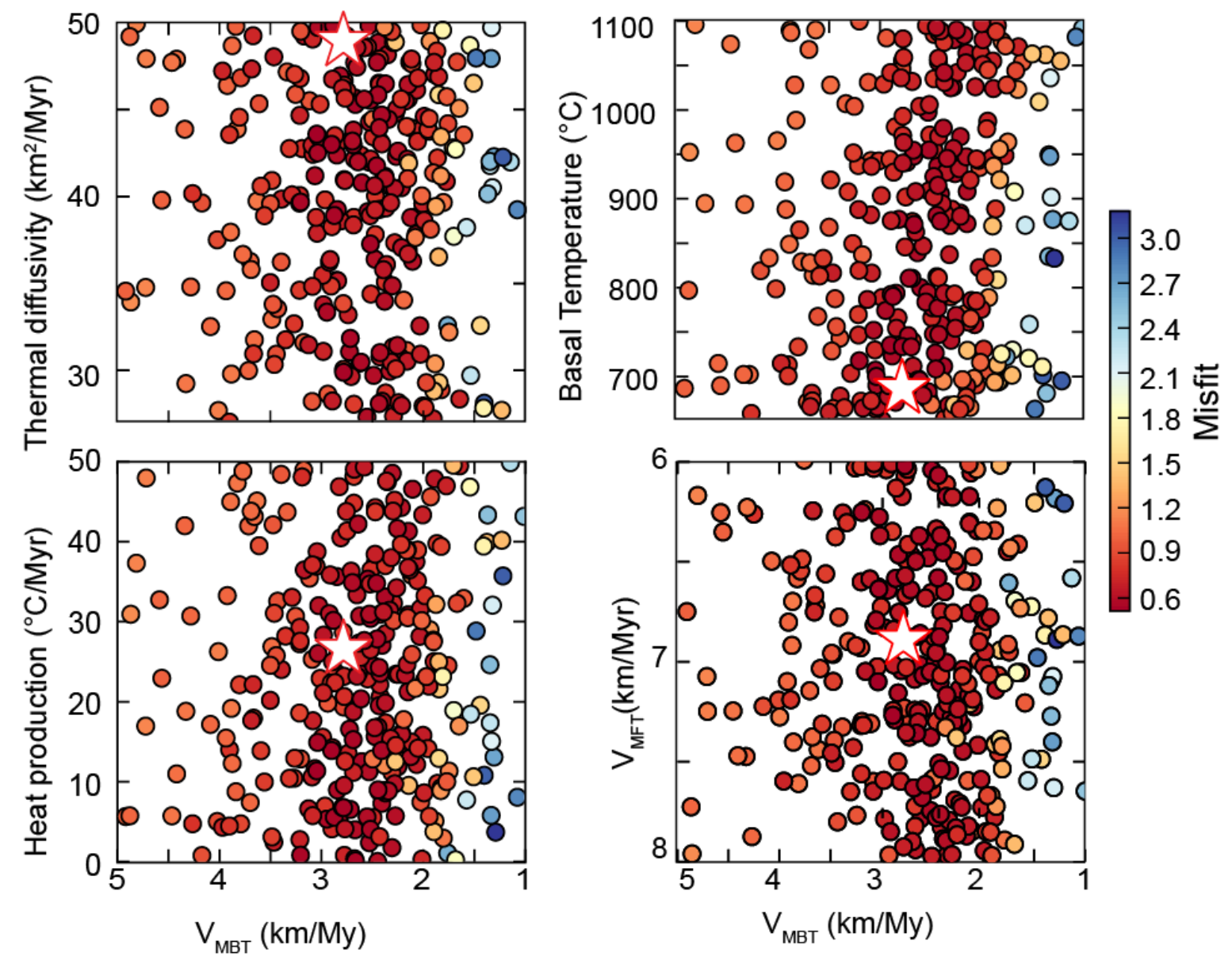

Fig. S6. Results of the inverse model runs. Two-dimensional sections through the 5parameters space, in which each model (parameter combination) is represented by a colored dot according to the misfit between predicted and observed data. White star shows the location of best-fit model reported in table 2 .

\section{$\underline{\text { Basal Temperature }}$}

The basal temperature has strong effects on the ZHe thermochronometer (Fig. S3, S4), while the AFT ages seem to be relatively unviolated, except for lower temperatures. Optimal basal values seems to range from $750^{\circ} \mathrm{C}$ to $800^{\circ} \mathrm{C}$, since all ages where determined from the overthrusted hanging wall material, that never exceeds shallow crustal depths.

\section{$\underline{\text { References }}$}

Braun, J., van der Beek, P., Valla, P., Robert, X., Herman, F., Glotzbach, C., Pedersen, V., Perry, C., Simon-Labric, T., and Prigent, C., 2012, Quantifying rates of landscape evolution and tectonic 
processes by thermochronology and numerical modeling of crustal heat transport using PECUBE: Tectonophysics, v. 524-525, p. 1-28.

Coutand, I., Whipp, D.M., Grujic, D., Bernet, M., Fellin, M.G., Bookhagen, B., Landry, K.R., Ghalley, S.K., and Duncan, C., 2014, Geometry and kinematics of the Main Himalayan Thrust and Neogene crustal exhumation in the Bhutanese Himalaya derived from inversion of multithermochronologic data: Journal of Geophysical Research: Solid Earth, v. 119, p. 14461481.

Farley, K.A., Wolf, R.A., and Silver, L.T., 1996, The effects of long alpha-stopping distances on (UTh)/He ages: Chemical Geology, v. 60, p. 4223-4229.

Huntington, K.W., Ehlers, T.A., Hodges, K.V., and Whipp, D.M., 2007, Topography, exhumation pathway, age uncertainties, and the interpretation of thermochronometer data: Tectonics, $v$. 26.

Kundu, B., Yadav, R.K., Bali, B.S., Chowdhury, S., and Gahalaut, V.K., 2014, Oblique convergence and slip partitioning in the NW Himalaya: Implications from GPS measurements: Tectonics, v. 33, p. 2013-2024.

Powers, P.M., Lillie, R.J., and Yeats, R.S., 1998, Structure and shortening of the Kangra and Dehra Dun reentrants, sub-Himalaya, India: Geological Society of America Bulletin, v. 110, p. 1010-1027.

Rajendra Prasad, B., Klemperer, S.L., Vijaya Rao, V., Tewari, H.C., and Khare, P., 2011, Crustal structure beneath the Sub-Himalayan fold-thrust belt, Kangra recess, northwest India, from seismic reflection profiling: Implications for Late Paleoproterozoic orogenesis and modern earthquake hazard: Earth and Planetary Science Letters, v. 308, p. 218-228.

Schulte-Pelkum, V., Monsalve, G., Sheehan, A., Pandey, M.R., Sapkota, S., Bilham, R., and Wu, F., 2005, Imaging the Indian subcontinent beneath the Himalaya: Nature, v. 435, p. 1222-1225.

Stübner, K., Drost, K., Schoenberg, R., Böhme, M., Starke, J., and Ehlers, T.A., 2016, Asynchronous timing of extension and basin formation in the South Rhodope core complex, SW Bulgaria, and northern Greece: Tectonics, v. 35, p. 136-159.

Valla, P.G., van der Beek, P.A., and Braun, J., 2011, Rethinking low-temperature thermochronology data sampling strategies for quantification of denudation and relief histories: A case study in the French western Alps: Earth and Planetary Science Letters, v. 307, p. 309-322. 